\title{
Short Communication: The composition of undergrowth vegetation in the Gendol Riverbank, Sleman District, Yogyakarta, Indonesia
}

\author{
ATUS SYAHBUDIN ${ }^{1, \vartheta}$, ALNUS MEINATA ${ }^{1, \vee v}$, RIDLA ARIFRIANA $^{2, \bullet \vee \vee}$, WIYONO $^{1}$ \\ ${ }^{1}$ Forestry Program, Faculty of Forestry, Universitas Gadjah Mada. Jl. Agro No. 1, Bulaksumur, Sleman 55281, Yogyakarta, Indonesia. \\ Tel./fax.: +62-274-550541, `email: syahbudin_atus@gadjahmada.edu. vv alnusmeinata@gmail.com, alnus.meinata@ mail.ugm.ac.id \\ ${ }^{2}$ Forest Management Program, Department of Veterinary and Biotechnology, Vocational School, Universitas Gadjah Mada. Jl. Jacaranda Sekip II, \\ Sleman 55281, Yogyakarta, Indonesia. Tel.: +62-274-541020, ${ }^{\cdots v}$ email: ridha.arifriana@gmail.com
}

Manuscript received: 13 February 2020. Revision accepted: 4 April 2020

\begin{abstract}
Syahbudin A, Meinata A, Arifriana R, Wiyono. 2020. The composition of undergrowth vegetation in the Gendol Riverbank, Sleman District, Yogyakarta, Indonesia. Biodiversitas 21: 1786-1792. Gendol river is one of the rivers affected by a pyroclastic blast from Mount Merapi eruption in 2010. This river flows through several villages, such as Glagaharjo, Kepuharjo, Wukirsari, and Argomulyo. On this riverbank, vegetation has grown naturally post-eruption of Mount Merapi and is continues to change. Some vegetation was also planted by the community. This study aims to find out the composition of the undergrowth vegetation on the Gendol riverbank in Cangkringan Sub-district. The data was obtained systematically by marking 10 sample plots of $5 \mathrm{~m} \times 5 \mathrm{~m}$ and $2 \mathrm{~m} \times 2 \mathrm{~m}$ size, on each side of the bank. A total of 68 species were recorded in this study which consisted of 29 trees species in seedlings and saplings stage, 34 species of herbs and shrubs, and 6 species of grasses. The dominant among the non-tree species are Chromolaena odorata (L.) R.M.King \& H.Rob. with an IVI of 43.78\%, Alternanthera brasiliana (L.) Kuntze with IVI of $16.6 \%$ and Asystasia gangetica (L.) T. Anderson with IVI of $15.78 \%$. Saplings are dominated by Falcataria moluccana (Miq.) Barneby \& J.W. Grimes with IVI of 32.81\%, followed by Leucaena leucocephala (Lam.) De Wit (IVI-24.41\%) and Melia azedarach (IVI-14.28\%).
\end{abstract}

Keywords: Gendol Riverbank, seedlings, species composition, understorey

\section{INTRODUCTION}

Yogyakarta City is the capital of Yogyakarta Special Province, situated in Central Java, Indonesia and it's located at a distance of about $30 \mathrm{~km}$ from Mount Merapi (Karnawati 2006). Mount Merapi is a place well-known for its 'firing mountain', which is among the identified 129 most active volcanoes found in Java (Dove 2008). Mount Merapi is located on the border of cities namely, Sleman, Magelang, Boyolali, and Klaten (Geology Department 2011). This mountain has many rivers and one of them is Gendol river flowing in Sleman Regency, a part of the Opak Water Catchment Area. This finally joins the Opak river in the Sajaran Sub-village, Bimomartani Village, Ngemplak Sub-district, Sleman, Yogyakarta. Downstream part of the river does not reach the foot of Mount Merapi. River length from Gadingan Sub-village to Kayen Subvillage is approximately $7 \mathrm{~km}$. The coordinates of the Gendol river in that section are $7^{\circ} 39^{\prime} 30$ "LS- $7^{\circ} 43^{\prime} \mathrm{O}^{\prime \prime} \mathrm{LS}$ and $110^{\circ} 27^{\prime} 0$ "BT-110²9'0" BT (Sari 2014).

Mount Merapi is included in the most active volcanoes in Indonesia (Sutikno et al. 2007). Big explosion caused massive catastrophic impact in 2010 (Jenkins et al. 2014; Baxter et al. 2017). After the eruption, some areas of Sleman, mainly the surrounding of Opak, Boyong, Kuning and Gendol River, experienced lahars disaster (Suharyadi and Tuladhar 2010) which destroyed various important infrastructures such as settlements, bridge, agricultural and irrigation infrastructures, and so forth. One of them was pyroclastic blast in Cangkringan Sub-district (Rijal et al. 2010), which destroyed the rivers (Murwanto et al. 2013) and burnt whole vegetation on the riverbank (Jenkins et al. 2014). After the eruption, vegetation grew back naturally. The pioneers will determine the climax ecosystem of the future. If vegetation is well developed, it can protect the community around the Gendol river from pyroclastic blast material (Setyowati 2013). Vegetation has significant role in both environment and economy (Suharti 2015). Economically, the community can use the products for drugs, household equipment, green manure, cattle food, and others (Syahbudin et al. 2009, Farooquee and Saxena 1996). In mountain forests, vegetation regulates water systems, prevent erosion, keep cool air and mountainous landscapes (Listyaningrum et al. 2019). Riverside vegetation is a significant factor influencing the occurrence and progress of soil erosion, at the same time it also can regenerate the land productivity (Bruno et al. 2014). The increase of vegetation cover increases surface roughness, and reduces the size of bare crusted areas in between the vegetation (Cammeraat 2005). If the vegetation conditions are relatively poor, then tree enrichment is needed to overcome the problem. Therefore, data on the composition of the undergrowth vegetation on Gendol river is needed to support the activities. 


\section{MATERIALS AND METHODS}

\section{Study site}

The study was conducted in the Gendol riverbank in the Cangkingan Sub-district, Sleman District, Yogyakarta, Indonesia (Figure 1). Data collection period was from March 2017 to July 2017. Total riverbank distance studied was $1500 \mathrm{~m}$.

\section{Data collection}

The research was carried out by employing systematic sampling method which involved a total of 10 sampling quadrats established on either side of the river bank. The quadrat size was determined based on growth form, as described by Mueller-Dombois and Ellenberg (1974). 1, quadrats of $5 \mathrm{~m}$ x $5 \mathrm{~m}$ was marked for saplings, and $2 \mathrm{~m} \mathrm{x}$
$2 \mathrm{~m}$ for lower plants (herbs and shrubs), and seedlings. Saplings are young trees that have height more than $1.5 \mathrm{~m}$, but less than $10 \mathrm{~cm}$ in diameter breast height. Lower plant is ranging from grass, herb, and tree that have less than 1.5 $\mathrm{m}$ in height. The placing of the quadrats was not in a straight line and was based on the nature of the study site (Bartos et al. 1994), as shown in Figure 2.

\section{Data analysis}

The research data obtained from the quadrats were analyzed to obtain species composition and abundance of species in the plot. Each species was analyzed using the Important Value Index (IVI) and interpreted descriptively to understand the vegetation dynamics. Parameter observed was density and frequency with the formula:
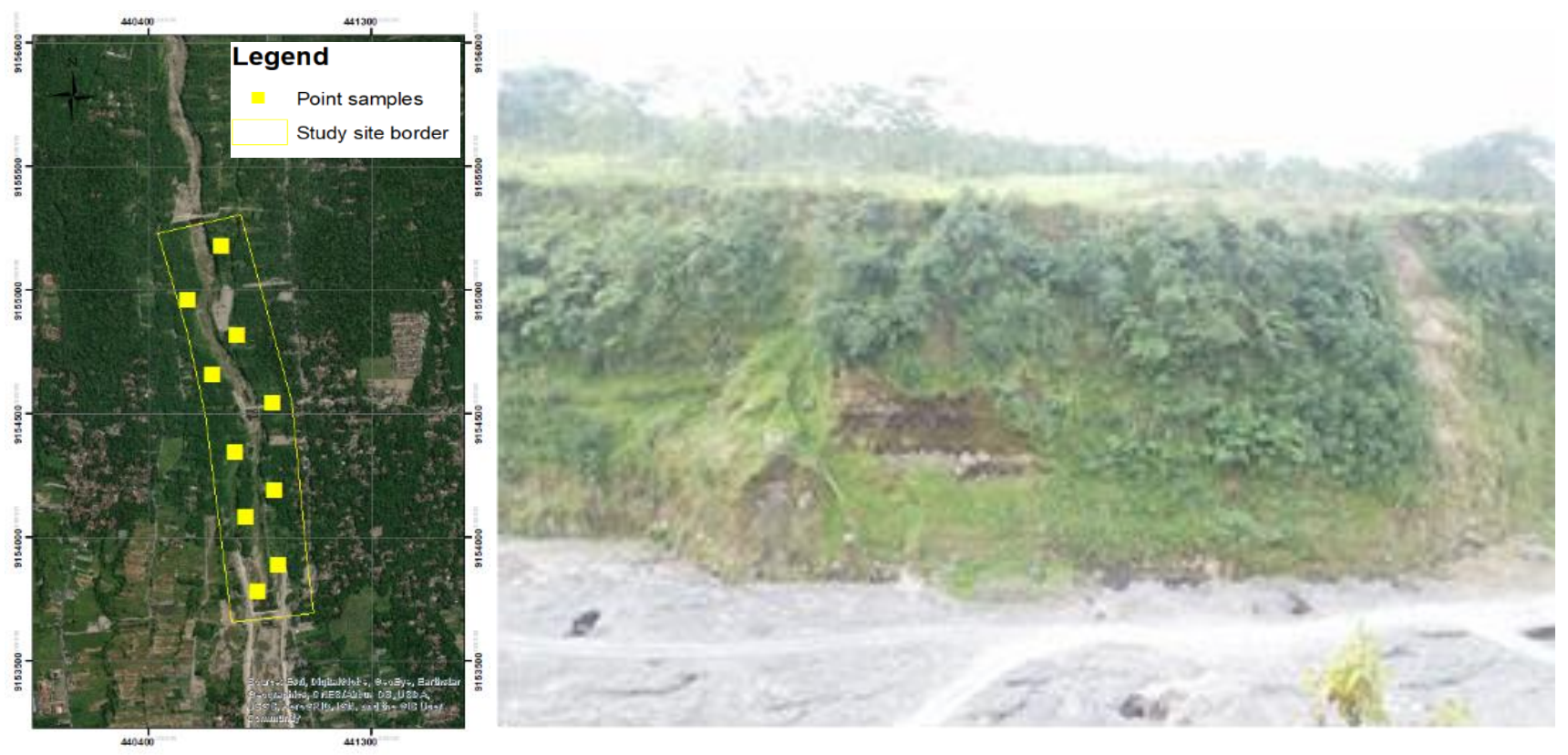

Figure 1. A. Study site Gendol river in Cangkingan Sub-district, Sleman District, Yogyakarta, Indonesia saw from above, B. Gendol river bank

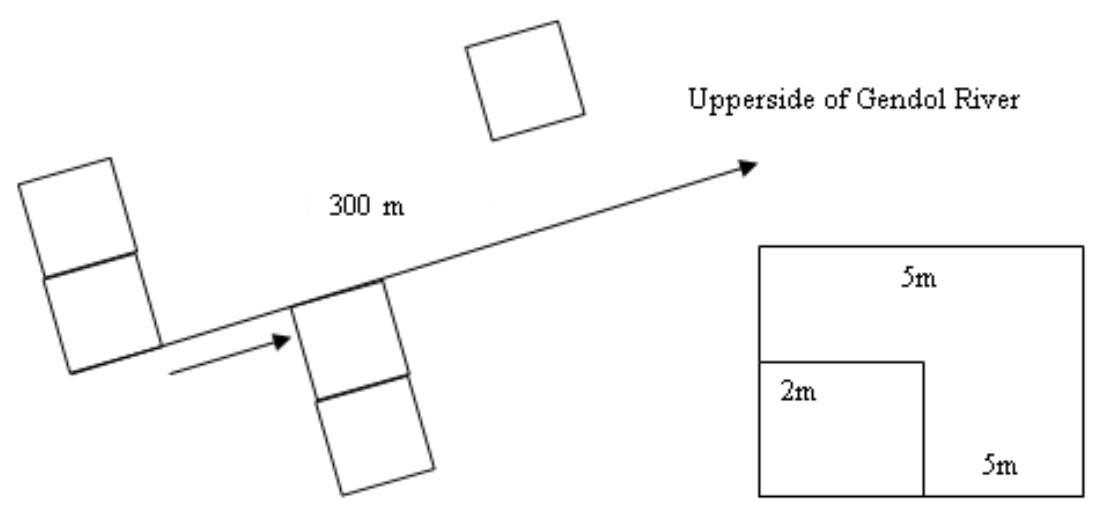

Figure 2. Location of research plots along Gendol Riverbank in Cangkingan Sub-district, Sleman District, Yogyakarta, Indonesia 


$$
\text { Frequency }(\%)=\frac{\text { Number of transects in which the species occur }}{\text { Total number of transects studied }} \times 100
$$$$
\text { Density }=\frac{\text { Total number of individuals of the species }}{\text { Total number of transects studied }}
$$

Then the Domination calculated with the formula Frequency + Density.

\section{RESULTS AND DISCUSSION}

In this study, undergrowth means all those plants that have herbaceous and shrub habits, including seedlings and saplings of tree species. The saplings and seedlings indicate regeneration status of forest (Septiawan et al. 2017). Connell (1989), is of the opinion that the seedlings can represent forest gaps which reflect the status of forest health. The composition of the vegetation of the Gendol river banks in the Cangkringan Sub-district can be seen in Table 1.

A total of 68 undergrowth species have been recorded, including herbaceous plants, shrubs, grasses, and trees. It consists of 29 species of trees in seedling and sapling stages, 33 species of herbs and shrubs, and 6 species of grasses. Vegetation that survived in the area may be reestablished after volcanic eruption (Dale et al. 2005). Habitat loss can cause a threat to biodiversity to eliminate some important species in the area (With 2002). Optimally a disturbed area such as post-eruption area should be restored with native plants to maintain the biodiversity in the area (Matsumoto et. al. 2015). Some of the exotic species can be established, namely needlewood tree (Schima wallichii), hopbush (Dodonaea viscosa), dapdap (Erythrina lithosperma), and arngoni (Vaccinium varingiaefolium) (Umaya 2013). But some of the plants can be risky since they are invasive species (Meekins and McCarthy 2001). Invasive species can threaten biodiversity in the area especially in ecosystem service to maintain the surroundings (Charles and Dukes 2008).

The IVI values for herbs, shrubs, and seedlings, along with their frequency, relative frequency, density, and relative density is provided in Table 2. The highest IVI value of $43.7 \%$ was obtained for Chromolaena odorata. Next two species are Alternanthera brasiliana with IVI of $16.61 \%$ and Asystasia gangetica with $15.78 \%$. All of the tree saplings had low IVI than herbs, shrubs, and seedlings (Table 3). Shrubs were found in the least amount but the number of individuals was quite large, especially for $C$. odorata.

Among the saplings, Falcataria moluccana and Leucaena leucocephala showed the highest IVI. The IVI for F. moluccana was $32.81 \%$, L. leucocephala was $24.41 \%$, and $M$. azedarach was $14.28 \%$. They are followed by Muntingia calabura, Senna siamea, Melochia umbellata, F. hispida, and Talipariti simile all of which have IVI of $9.52 \%$.
Table 1. Composition of undergrowth vegetation in Gendol riverbank, Indonesia post-eruption of Mount Merapi 2010

\begin{tabular}{|c|c|c|}
\hline Species & Family & Habit \\
\hline Albizia lebbeck (L.) Benth. & Fabaceae & Tree \\
\hline Albizia procera (Roxb.) Benth. & Fabaceae & Tree \\
\hline Annona muricata $\mathrm{L}$. & Annonaceae & Tree \\
\hline Antidesma bunius (L.) Spreng. & Euphorbiaceae & Tree \\
\hline Artocarpus heterophyllus Lam. & Moraceae & Tree \\
\hline Senna siamea (Lam.) H.S.Irwin \& Barneby & Fabaceae & Tree \\
\hline Cocos nucifera L. & Aracaceae & Tree \\
\hline Dalbergia latifolia Roxb. & Fabaceae & Tree \\
\hline Durio zibethinus Murray & Bombacaceae & Tree \\
\hline Dysoxylum gaudichaudianum (A.Juss.) Miq & Meliaceae & Tree \\
\hline Lepisanthes rubiginosa (Roxb.) Leenh. & Sapindaceae & Tree \\
\hline Eugenia polyantha Barb. Rodr. & Myrtaceae & Tree \\
\hline \multicolumn{3}{|l|}{ Falcataria moluccana (Miq.) Barneby \& } \\
\hline J.W.Grimes & Fabaceae & Tree \\
\hline Ficus grossularioides Burm.f. & Moraceae & Tree \\
\hline Ficus hispida L.f. & Moraceae & Tree \\
\hline Ficus septica Burm.f. & Moraceae & Tree \\
\hline Gliricidia sepium (Jacq.) Walp. & Fabaceae & Tree \\
\hline Talipariti simile (Blume) Fryxell & Malvaceae & Tree \\
\hline Leucaena leucocephala (Lam.) de Wit & Fabaceae & Tree \\
\hline Mangifera indica L. & Anacardiaceae & Tree \\
\hline Melia azedarach $\mathrm{L}$. & Meliaceae & Tree \\
\hline Melochia umbellata (Houtt.) Stapf & Malvaceae & Tree \\
\hline Muntingia calabura L. & Muntingiaceae & Tree \\
\hline Parkia speciosa Hassk. & Fabaceae & Tree \\
\hline Pterospermum javanicum Jung. & Sterculiaceae & Tree \\
\hline Albizia saman (Jacq.) Merr. & Fabaceae & Tree \\
\hline Syzygium aqueum (Burm.f.) Alston & Myrtaceae & Tree \\
\hline Syzygium cumini (L.) Skeels. & Myrtaceae & Tree \\
\hline Swietenia macrophylla King. & Meliaceae & Tree \\
\hline Calotropis gigantea (L.) Dryand. & Apocynaceae & Shrub \\
\hline Chromolaena odorata (L.) R.M.King \& H.Rob. & Verbenaceae & Shrub \\
\hline Lantana camara $\mathrm{L}$. & Asteraceae & Shrub \\
\hline Manihot esculenta Crantz. & Euphorbiaceae & Shrub \\
\hline Sida rhombifolia $\mathrm{L}$. & Malvaceae & Shrub \\
\hline Urena lobata $\mathrm{L}$. & Malvaceae & Shrub \\
\hline Aeschynomene indica $\mathrm{L}$. & Fabaceae & Herb \\
\hline Asystasia gangetica (L.) T.Anderson & Acanthaceae & Herb \\
\hline Axonopus compressus (Sw.) P. Beauv. & Poaceae & Herb \\
\hline Ageratum conyzoides (L.) L. & Asteraceae & Herb \\
\hline Crassocephalum crepidioides (Benth.) S.Moore & Asteraceae & Herb \\
\hline Blumea balsamifera (L.) DC. & Asteraceae & Herb \\
\hline Spermacoce alata Aubl. & Rubiaceae & Herb \\
\hline Cyclea barbata Miers. & Menispermaceae & Herb \\
\hline Dicksonia sp. & Polypodiaceae & Herb \\
\hline Drynaria quercifolia (L.) J. Sm. & Polypodiaceae & Herb \\
\hline Crassocephalum $\mathrm{sp}$. & Asteraceae & Herb \\
\hline Stachytarpheta indica (L.) Vahl & Verbenaceae & Herb \\
\hline Brachiaria mutica (Forssk.) Stapf & Poaceae & Herb \\
\hline Plectranthus monostachyus (P. Beauv.) B.J. Pollard & Lamiaceae & Herb \\
\hline Mikania micrantha Kunth & Asteraceae & Herb \\
\hline Syngonium podophyllum Schott & Araceae & Herb \\
\hline Ptyrogramma sp. & Polypodiaceae & Herb \\
\hline Pteris sp. & Polypodiaceae & Herb \\
\hline Gleicheina sp. & Gleicheniaceae & Herb \\
\hline Carica papaya $\mathrm{L}$. & Caricaceae & Herb \\
\hline Musa paradisiaca $\mathrm{L}$. & Musaceae & Herb \\
\hline Pteris sp. & Polypodiaceae & Herb \\
\hline Mimosa pudica $\mathrm{L}$. & Fabaceae & Herb \\
\hline Centrosema pubescens Benth. & Fabaceae & Herb \\
\hline Alternanthera brasiliana (L.) Kuntze & Amaranthaceae & Herb \\
\hline Solanum torvum $\mathrm{Sw}$. & Solanaceae & Herb \\
\hline Tridax procumbens (L.) L. & Asteraceae & Herb \\
\hline Imperata cylindrica (L.) Raeusch. & Poaceae & Grass \\
\hline Melinis sp. & Poaceae & Grass \\
\hline Sporobolus sp. & Lamiaceae & Grass \\
\hline Melinis repens (Willd.) Zizka & Poaceae & Grass \\
\hline Oplismenus burmannii (Retz.) P.Be & Poaceae & Grass \\
\hline Themeda arguens (L.) Hack. & Poaceae & Grass \\
\hline
\end{tabular}


Table 2. Frequency, relative frequency, density, relative density and important value index (IVI) for herbs, shrubs and saplings in Gendol river bank in Cangkringan Sub-district, Sleman District, Yogyakarta, Indonesia post-eruption of Mount Merapi in 2010

\begin{tabular}{|c|c|c|c|c|c|}
\hline Species & $\mathbf{F}$ & FR $(\%)$ & $\mathbf{K}$ & KR $(\%)$ & IVI \\
\hline Chromolaena odorata (L.) R.M.King \& H.Rob. & 0.90 & 12.59 & 32125.00 & 31.19 & 43.78 \\
\hline Alternanthera barasiliana (L.) Kuntze & 0.45 & 6.29 & 10625.00 & 10.32 & 16.61 \\
\hline Asystasia gangetica (L.) T.Anderson & 0.20 & 2.80 & 13375.00 & 12.99 & 15.78 \\
\hline Plectranthus monostachyus (P.Beauv.) B.J.Pollard & 0.20 & 2.80 & 6250.00 & 6.07 & 8.87 \\
\hline Urena lobata $\mathrm{L}$. & 0.30 & 4.20 & 4125.00 & 4.00 & 8.20 \\
\hline Centrosema pubescens Benth. & 0.30 & 4.20 & 2875.00 & 2.79 & 6.99 \\
\hline Brachiaria mutica (Forssk.) Stapf & 0.25 & 3.50 & 2875.00 & 2.79 & 6.29 \\
\hline Melinis repens (Willd.) Zizka & 0.20 & 2.80 & 3375.00 & 3.28 & 6.07 \\
\hline Crassocephalum sp. & 0.25 & 3.50 & 2500.00 & 2.43 & 5.92 \\
\hline Manihot esculenta Crantz. & 0.20 & 2.80 & 1875.00 & 1.82 & 4.62 \\
\hline Pteris sp. & 0.05 & 0.70 & 3625.00 & 3.52 & 4.22 \\
\hline Leucaena leucocephala (Lam.) de Wit & 0.20 & 2.80 & 1250.00 & 1.21 & 4.01 \\
\hline Musa paradisiaca $\mathrm{L}$. & 0.20 & 2.80 & 1125.00 & 1.09 & 3.89 \\
\hline Blumea balsamifera (L.) DC. & 0.10 & 1.40 & 1875.00 & 1.82 & 3.22 \\
\hline Ficus septica Burm.f. & 0.10 & 1.40 & 1875.00 & 1.82 & 3.22 \\
\hline Ageratum conyzoides $(\mathrm{L}.) \mathrm{L}$ & 0.10 & 1.40 & 1250.00 & 1.21 & 2.61 \\
\hline Mimosa pudica L. & 0.15 & 2.10 & 375.00 & 0.36 & 2.46 \\
\hline Dacksonia sp. & 0.10 & 1.40 & 1000.00 & 0.97 & 2.37 \\
\hline Stachytarpheta indica (L.) Vahl & 0.10 & 1.40 & 625.00 & 0.61 & 2.01 \\
\hline Lantana camara $\mathrm{L}$. & 0.10 & 1.40 & 500.00 & 0.49 & 1.88 \\
\hline Melia azedarach $\mathrm{L}$. & 0.10 & 1.40 & 500.00 & 0.49 & 1.88 \\
\hline Glirisidia sepium (Jacq.) Walp. & 0.10 & 1.40 & 500.00 & 0.49 & 1.88 \\
\hline Swietenia macrophylla King. & 0.10 & 1.40 & 375.00 & 0.36 & 1.76 \\
\hline Sida rhombifolia L. & 0.10 & 1.40 & 250.00 & 0.24 & 1.64 \\
\hline Ficus hispida L.f. & 0.10 & 1.40 & 250.00 & 0.24 & 1.64 \\
\hline Melochia umbellata (Houtt.) Stapf & 0.10 & 1.40 & 250.00 & 0.24 & 1.64 \\
\hline Axonopus compressus (Sw.) P.Beauv. & 0.10 & 1.40 & 250.00 & 0.24 & 1.64 \\
\hline Spermacoce alata Aubl. & 0.10 & 1.40 & 125.00 & 0.12 & 1.52 \\
\hline Durio zibethinus Murray & 0.10 & 1.40 & 125.00 & 0.12 & 1.52 \\
\hline Crassocephalum crepidioides (Benth.) S.Moore & 0.10 & 1.40 & 125.00 & 0.12 & 1.52 \\
\hline Ptyrogramma sp. & 0.10 & 1.40 & 125.00 & 0.12 & 1.52 \\
\hline Annona muricata $\mathrm{L}$. & 0.10 & 1.40 & 125.00 & 0.12 & 1.52 \\
\hline Muntingia calabura $\mathrm{L}$. & 0.10 & 1.40 & 125.00 & 0.12 & 1.52 \\
\hline Artocarpus heterophyllus Lam. & 0.10 & 1.40 & 125.00 & 0.12 & 1.52 \\
\hline Pteris sp. & 0.10 & 1.40 & 125.00 & 0.12 & 1.52 \\
\hline Ptyrogramma sp. & 0.10 & 1.40 & 125.00 & 0.12 & 1.52 \\
\hline Imperata cylindrica (L.) Raeusch. & 0.05 & 0.70 & 750.00 & 0.73 & 1.43 \\
\hline Themeda arguens (L.) Hack. & 0.05 & 0.70 & 625.00 & 0.61 & 1.31 \\
\hline Tridax procumbens (L.) L. & 0.05 & 0.70 & 625.00 & 0.61 & 1.31 \\
\hline Dalbergia latifolia Roxb. & 0.05 & 0.70 & 625.00 & 0.61 & 1.31 \\
\hline Drynaria quercifolia (L.) J. Sm. & 0.05 & 0.70 & 375.00 & 0.36 & 1.06 \\
\hline Monstera sp. & 0.05 & 0.70 & 375.00 & 0.36 & 1.06 \\
\hline Lepisanthes rubiginosa (Roxb.) Leenh. & 0.05 & 0.70 & 250.00 & 0.24 & 0.94 \\
\hline Sporobolus sp. & 0.05 & 0.70 & 250.00 & 0.24 & 0.94 \\
\hline Gleicheina sp. & 0.05 & 0.70 & 250.00 & 0.24 & 0.94 \\
\hline Calotropis gigantea (L.) Dryand. & 0.05 & 0.70 & 250.00 & 0.24 & 0.94 \\
\hline Cocos nucifera $\mathrm{L}$. & 0.05 & 0.70 & 250.00 & 0.24 & 0.94 \\
\hline Albizia lebbeck (L.) Benth. & 0.05 & 0.70 & 125.00 & 0.12 & 0.82 \\
\hline Ciclea barbata Miers. & 0.05 & 0.70 & 125.00 & 0.12 & 0.82 \\
\hline Mikania micrantha Kunth & 0.05 & 0.70 & 125.00 & 0.12 & 0.82 \\
\hline Aeschinomene indica $\mathrm{L}$. & 0.05 & 0.70 & 125.00 & 0.12 & 0.82 \\
\hline Melinis repens (Willd.) Zizka & 0.05 & 0.70 & 125.00 & 0.12 & 0.82 \\
\hline Mangifera indica $\mathrm{L}$. & 0.05 & 0.70 & 125.00 & 0.12 & 0.82 \\
\hline Carica papaya $\mathrm{L}$. & 0.05 & 0.70 & 125.00 & 0.12 & 0.82 \\
\hline Eugenia polyantha Barb. Rodr. & 0.05 & 0.70 & 125.00 & 0.12 & 0.82 \\
\hline Oplismenus burmanni (Retz.) P.Beauv. & 0.05 & 0.70 & 125.00 & 0.12 & 0.82 \\
\hline Pterospermum javanicum Jung. & 0.05 & 0.70 & 125.00 & 0.12 & 0.82 \\
\hline Solanum torvum $\mathrm{Sw}$. & 0.05 & 0.70 & 125.00 & 0.12 & 0.82 \\
\hline Sum & 7.15 & 100.00 & 103000.00 & 100.00 & 200.00 \\
\hline
\end{tabular}

Note: F : Frequency, FR: Frequency Relative, K: Density, KR: Density Relative, IVI: Important Value Index 
Table 3. Frequency, relative frequency, density, relative density and important value index (IVI) for saplings in Gendol riverbank in Cangkringan Sub-district, Sleman District, Yogyakarta, Indonesia, post-eruption of Mount Merapi 2010

\begin{tabular}{|c|c|c|c|c|c|}
\hline Species & $\mathbf{F}$ & FR $(\%)$ & $\mathbf{K}$ & KR $(\%)$ & IVI \\
\hline Falcataria moluccana (Miq.) Barneby \& J.W.Grimes & 0.30 & 15.79 & 160.00 & 17.02 & 32.81 \\
\hline Leucaena leucocephala (Lam.) de Wit & 0.10 & 5.26 & 180.00 & 19.15 & 24.41 \\
\hline Melia azedarach $\mathrm{L}$. & 0.15 & 7.89 & 60.00 & 6.38 & 14.28 \\
\hline Muntingia calabura $\mathrm{L}$. & 0.10 & 5.26 & 40.00 & 4.26 & 9.52 \\
\hline Senna siamea (Lam.) H.S.Irwin \& Barneby & 0.10 & 5.26 & 40.00 & 4.26 & 9.52 \\
\hline Melochia umbellata (Houtt.) Stapf & 0.10 & 5.26 & 40.00 & 4.26 & 9.52 \\
\hline Ficus hispida L.f. & 0.10 & 5.26 & 40.00 & 4.26 & 9.52 \\
\hline Talipariti simile (Blume) Fryxell & 0.10 & 5.26 & 40.00 & 4.26 & 9.52 \\
\hline Syzygium cumini (L.) Skeels. & 0.05 & 2.63 & 20.00 & 2.13 & 4.76 \\
\hline Antidesma bunius (L.) Spreng. & 0.05 & 2.63 & 20.00 & 2.13 & 4.76 \\
\hline Syzygium aqueum (Burm.f.) Alston & 0.05 & 2.63 & 20.00 & 2.13 & 4.76 \\
\hline Ficus septica Burm.f. & 0.05 & 2.63 & 20.00 & 2.13 & 4.76 \\
\hline Ficus grossularioides Burm.f. & 0.05 & 2.63 & 20.00 & 2.13 & 4.76 \\
\hline Cocos nucifera $\mathrm{L}$. & 0.05 & 2.63 & 20.00 & 2.13 & 4.76 \\
\hline Durio zibethinus Murray & 0.05 & 2.63 & 20.00 & 2.13 & 4.76 \\
\hline Gliricidia sepium (Jacq.) Walp. & 0.05 & 2.63 & 20.00 & 2.13 & 4.76 \\
\hline Albizia lebbeck (L.) Benth. & 0.05 & 2.63 & 20.00 & 2.13 & 4.76 \\
\hline Dalbergia latifolia Roxb. & 0.05 & 2.63 & 20.00 & 2.13 & 4.76 \\
\hline Albizia saman (Jacq.) Merr. & 0.05 & 2.63 & 20.00 & 2.13 & 4.76 \\
\hline Dysoxylum gaudichaudianum (A.Juss.) Miq & 0.05 & 2.63 & 20.00 & 2.13 & 4.76 \\
\hline Lepisanthes rubiginosa (Roxb.) Leenh. & 0.05 & 2.63 & 20.00 & 2.13 & 4.76 \\
\hline Parkia speciosa Hassk. & 0.05 & 2.63 & 20.00 & 2.13 & 4.76 \\
\hline Swietenia macrophylla King. & 0.05 & 2.63 & 20.00 & 2.13 & 4.76 \\
\hline Artocarpus heterophyllus Lam. & 0.05 & 2.63 & 20.00 & 2.13 & 4.76 \\
\hline Albizia procera (Roxb.) Benth. & 0.05 & 2.63 & 20.00 & 2.13 & 4.76 \\
\hline Sum & 1.9 & 100 & 940 & 100 & 200 \\
\hline
\end{tabular}

Seven years after the eruption of Mount Merapi, the banks of the Gendol river in the Cangkringan Sub-district has undergrowth vegetation consisting of herbs, shrubs, grasses, and seedlings and saplings of trees. The cause of the destruction was high pyroclastic material that emerged from the mountain (Jenkins et al. 2013). The population of saplings was very low. On the other hand, herbs appear to dominate. Herbs are plants that grow easily, but also die quickly. The presence of saplings, herbs, shrubs, and grasses is an indication that succession is in progress (Vázquez-Yanes and Orozco-Segovia 1982), and the climax level is yet to be reached (Yusuf and Sukardjo 2016). However, the climax condition can be predicted from the present condition. Saplings of species such as $F$. moluccana and L. leucocephala dominate the undergrowth. This indicates that the seedlings of both of these species were able to live and adapt well. Both are considered as the most suitable and desirable species by the community because they have high economic value. Undergrowth vegetation also plays important role in nutrient cycling. It adds significant amounts of $\mathrm{N}, \mathrm{Ca}$, and $\mathrm{Mn}$, and there was more than twice the amount of $\mathrm{K}$ in the litter fall under herbs than when these undergrowth layers were absent (Tappeiner and Alm 1975).

\section{ACKNOWLEDGEMENTS}

We would like to thank the chief of Bimomartani Village, Yogyakarta, Indonesia, the head of the Sajaran
Sub-village and the communities around the research location who have helped us in data collection. This research was carried out with the help of public funds through the Faculty of Forestry, Gadjah Mada University, Indonesia research grant.

\section{REFERENCES}

Bartos DL, Brown JK, Booth GD. 1994. Twelve years of biomass response in aspen communities following fire. J Range Manag 47 (1): 79-83.

Baxter PJ, Jenkins S, Seswandhana R, Komorowski J, Dunn K, Purser D, Voight B, Shelley I. 2017. Human survival in volcanic eruptions: Thermal injuries in pyroclastic surges, their causes, prognosis and emergency management. Burns 43 (5): 1051-1069.

Bruno D, Belmar O, Sánchez-Fernández D, Guareschi S, Millán A, Velasco J. 2014. Responses of Mediterranean aquatic and riparian communities to human pressures at different spatial scales. Ecol Indicat 45: 456-464

Cammeraat E, van Beek R, Kooijman A. 2005. Vegetation succession and its consequences for slope stability in SE Spain. Plant Soil 278 (1-2): 135-147.

Charles H, Dukes JS. 2008. Impacts of invasive species on ecosystem services. In: Biological Invasions. Springer, Berlin.

Connell JH. 1989. Some processes affecting the species composition in forest gaps. Ecology 70 (3): 560-562.

Dale VH, Delgado-Acevedo J, MacMahon J. 2005. Effects of modern volcanic eruptions on vegetation. In: Martí J, Ernst GGJ (eds.). Volcanoes and the Environment. Cambridge University Press, Cambridge.

Dove MR. 2008. Perception of volcanic eruption as agent of change on Merapi volcano, Central Java. J Volcanol Geothermal Res 172: 329337. 
Farooquee NA, Saxena KG. 1996. Conservation and utilization of medicinal plants in high hills of the central Himalayas. Environ Conserv 23 (1): 75-80.

Geology Department. 2011. Indonesian Volcano Basic Data (Data Dasar Gunung Api Indonesia). 2nd ed. Ministry of Energy and Mineral Resources. Bandung, Indonesia. [Indonesian]

Jenkins S, Komorowski JC, Baxter PJ, Spence R, Picquout A, Lavigne F. 2013. The Merapi 2010 eruption: An interdisciplinary impact assessment methodology for studying pyroclastic density current dynamics. J Volcanol Geothermal Res 261: 316-329.

Jenkins SF, Spence RJS, Fonseca JFBD, Solidum RU, Wilson TM. 2014 Volcanic risk assessment: Quantifying physical vulnerability in the built environment. J Volcanol Geothermal Res 276: 105-120.

Karnawati D, Pramumijoyo S, Hendrayana H. 2006. Geology of Yogyakarta, Java: the dynamic volcanic arc city. The 10th IAEG International Congress, Nottingham, United Kingdom, 6-10 September 2006, Paper number 363.

Listyaningrum N, Nisa AK, Hidayatullah L, Ihsanjaya MMM, Janah SN, Sugureta NM, Fatkhurrohman W, Primasanti H, Ngadianto A, Sulaiman A, Syahbudin A. 2019. Water quality as a base of water treatment with appropriate technology in Girikerto Village, Sine Subdistrict, Ngawi Regency. IOP Conf Ser Earth Environ Sci 256 (1): 012013. DOI: 10.1088/1755-1315/256/1/012013.

Matsumoto K, Noerdjito WA, Cholik E, Sarino. 2015. Biodiversity Restoration by Plantation (Based on the study in Lombok, Indonesia). Japan International Forestry Promotion and Cooperation Center, Tokyo.

Meekins FJ, McCarthy BC. 2001. Effect of environmental variation on the invasive success of a nonindigenous forest herb. Ecol Appl 11 (5): 1336-1348.

Mueller-Dombois D, Ellenberg H. 1974. Aims and Methods of Vegetation Ecology. John Wiley and Sons, New York.

Murwanto H, Siregar DA, Purwoarminta A. 2013. The eruption of Mount Merapi in Magelang Regency, Central Java Province (Jejak erupsi Gunung Merapi di Kabupaten Magelang Provinsi Jawa Tengah). Jurnal Lingkungan dan Bencana Geologi 4 (2): 135-147. [Indonesian]

Rijal SS, Rukmana MJ, Prasaja AS. 2010. Detection of Damage to Land Use due to Merapi Hot Clouds in 2010 Using Remote Sensing (Deteksi Kerusakan Penggunaan Lahan Akibat Awan Panas Merap Tahun 2010 Menggunakan Pengindraan Jauh). Faculty of Geography, Universitas Gadjah Mada, Yogyakarta. [Indonesian]

Sari NP. 2014. Changes in the Morphology of the Middle Gendol River Due to the Rainfall of the Post-Eruption Volcano in 2010 (Perubahan Morfologi Sungai Gendol Bagian Tengah Akibat Lahar Hujan Pasca Erupsi Gunung Merapi 2010). [Thesis]. Faculty of Social Sciences, UNY, Yogyakarta. [Indonesian]
Septiawan W, Indriyanto I, Duryat D. 2017. Plants species, density, and crown stratification in community forests of Rukun Makmur 1 farmer group at Register 30 Gunung Tanggamus, Lampung (Jenis Tanaman, Kerapatan, dan Stratifikasi Tajuk pada Hutan Kemasyarakatan Kelompok Tani Rukun Makmur 1 di Register 30 Gunung Tanggamus, Lampung). Jurnal Sylva Lestari 5 (2): 88-101. [Indonesian]

Setyowati S, Hadi BS, Ashari A. 2013. Development of eruption hazard information system for disaster management in the south slope of Merapi Volcano (Pengembangan sistem informasi bahaya erupsi untuk pengelolaan kebencanaan di lereng selatan Gunungapi Merapi). Majalah Geografi Indonesia 27 (2): 138-148. [Indonesian]

Suharti S. 2015. Utilization of understorey in the utilization zone of Mount Merapi National Park by communities around the forest (Pemanfaatan tumbuhan bawah di zona pemanfaatan Taman Nasional Gunung Merapi oleh masyarakat sekitar hutan). Pros Sem Nas Masy Biodiv Indon 6 (1): 1411-1415. [Indonesian]

Suharyadi R, Tuladhar AM. 2010. Web-based spatial information system to support collaborative lahars disaster management. Indon J Geogr 44 (1): 96-114.

Sutikno, Santoso WL, Widiyanto, Kurniawan A, Purwanto TH. 2007. Merapi Kingdom (Kerajaan Merapi). Faculty of Geography, Universitas Gadjah Mada, Yogyakarta. [Indonesian]

Syahbudin A, Osozawa K, Ninomiya I, Adriyanti DT. 2009. The distribution of cemara udang (Casuarina equisetifolia) and its utilization along the southern coast of Bantul, Yogyakarta. Proceedings of JSPS-VCC Core University Program International Seminar on Wetlands and Sustainability, 26-28 June 2009, Le Meridien Hotel, Kota Kinabalu, Sabah. Volume 1: 173-182. Malaysia: Kulliyah dari Arsitektur \& Desain Lingkungan, International Islamic University Malaysia, Kuala Lumpur.

Tappeiner JC, Alm AA. 1975. Undergrowth vegetation effects on the nutrient content of litterfall and soils in red pine and birch stand in northern Minnesota. Ecology 56 (5): 1193-1200.

Umaya R. 2013. Plants Species on the North Slope of Merapi Mountain Selo Climbing Path (Jenis Tumbuhan di Lereng Utara Gunung Merapi Jalur Pendakian Selo). Balai Taman Nasional Gunung Merapi, Yogyakarta. [Indonesian]

Vázquez-Yanes C, Orozco-Segovia A. 1982. Seed germination of a tropical rain forest pioneer tree (Heliocarpus donnell-smithii) in response to diurnal fluctuation of temperature. Physiol Plant 56 (3): 295-298.

With KA. 2002. The landscape ecology of invasive spread. Conserv Biol 16 (5): 1192-1203.

Yusuf R, Sukardjo S. 2016. Lower vegetation in old stand of Cocos nucifera L. (Arecaceae) in Pari Island, Jakarta Bay (Vegetasi bawah di tegakan tua Cocos nucifera L. (Arecaceae) di Pulau Pari, Teluk Jakarta). Jurnal Teknologi Lingkungan 11 (2): 175-187. [Indonesian] 